\title{
The Implementation of Authentic Assessment in Thematic Learning in Elementary Schools
}

\author{
Debby Intan Safitri ${ }^{1}$, Mudzanata ${ }^{2}$, Anggun Dwi Setya Putri ${ }^{3}$
}

${ }^{123}$ Primary School Education Teachers, Faculty of Education, PGRI Semarang University, Indonesia

\author{
ARTICLEINFO \\ Article history: \\ Received 18 March 2020 \\ Received in revised form \\ 30 April 2020 \\ Accepted 5 May 2020 \\ Available online 15 May \\ 2020 \\ kata kunci: \\ kompetensi pedagogik, \\ penilaian autentik, \\ pembelajaran tematik \\ Keywords: \\ pedagogical competence, \\ authentic assessment, \\ thematic learning
}

\begin{abstract}
A B S TR A K
Permasalahan penelitian ini yaitu: a) anak kurang dapat mengembangkan nilai dan Tujuan dalam penelitian ini adalah untuk mengetahui kompetensi pedagogik guru dalam implementasi penilaian autentik pada pembelajaran tematik kelas II SD Negeri Pandeanlamper 01 Semarang. Latar belakang yang mendorong penelitian ini adalah guru masih mengalami kesulitan dalam mengimplementasikan penilain autentik. Jenis penelitian ini adalah penelitian kualitatif. Data dalam penelitian ini diperoleh melalui observasi, wawancara, dan dokumentasi. Hasil penelitian ini menunjukkan bahwa 1) guru dan kepala sekolah mengetahui tentang penilaian autentik dalam pembelajaran tematik 2) guru melaksanakan penilaian autentik yang mencakup penilaian kompetensi sikap, pengetahuan, dan keterampilan. Penilaian kompetensi sikap dilaksanakan melalui penilaian jurnal. Penilaian kompetensi pengetahuan dilaksanakan melalui teknik tes tulis dan penugasan. Penilaian kompetensi ketarmpilan dilaksanakan melalui teknik penilaian produk.
\end{abstract}

\section{A B S T R A C T}

The purpose of this study was to determine the teacher's pedagogical competence in the implementation of authentic assessment in the thematic learning of the second grade in SD Negeri (Public Elementary School) Pandeanlamper 01 Semarang. The background was due to teacher difficulty in implementing authentic assessments. The type of study was qualitative research. Data in this study were obtained through observation, interviews, and documentation. The results of this study indicate that 1) teachers and principals know about authentic assessments in thematic learning 2) teachers carry out authentic assessments that include assessment of competency attitudes, knowledge, and skills. The attitude competency assessment was conducted through a journal assessment. Knowledge competency assessment was conducted through written tests and assignment techniques. Skill competency assessment was conducted through product assessment techniques.

\section{Introduction}

The teacher is one of learning process determinants to achieve the goals of education through guiding, and educating the students. Becoming a professional teacher, the task of the teacher is not only teaching but also educating, guiding, listening and evaluating the students (Shabir, 2015). Being a good teacher is not an easy task, the teacher must master the competency. Teacher competence can be defined as the unity of knowledge, skills, and attitudes that is displayed in the form of intelligent and responsible behavior possessed by a teacher in carrying out his profession. The four competencies are professional competence, pedagogical competence, personal competence, and social competence. Government Regulation Number 19 of 2005 (Yovi Anggi Lestari dan Margaretha Purwanti, 2018). The most important competency for teachers is pedagogical competence.

Pedagogical competence is the teacher's competence in managing the learning process, as well as designing, implementing, and evaluating learning. (Yovi Anggi Lestari dan Margaretha Purwanti, 2018) insists that pedagogical competence is the ability to manage student learning which includes students' understanding, designing and implementing learning, evaluating learning

Copyright @ Universitas Pendidikan Ganesha. All rights reserved.

${ }^{1}$ Corresponding author.

E-mail addresses: debbys@gmail.com¹(Debby), Mudzanatun@gmail.com²(Mudzanatun),Anggun@gmail.com³(Mudzanatun) Copyright (c) Universitas Pendidikan Ganesha. All rights reserved. 
outcomes, and developing students to actualize their various potentials. In this competency, to be a competent teacher, the teacher is required to optimize the learning process. Hemalik (Novauli. M, 2015) states that competent teachers can create an effective, pleasant learning environment, and manage classrooms so that students can learn at an optimal level. The government has implemented a new curriculum called the 2013 curriculum. The challenge for teachers in this competency is the change of curriculum.

The changes of curriculum to the 2013 curriculum bring changes in learning, where learning in elementary schools apply thematic learning approach. (Kunandar, 2014) explains that thematic learning is a learning approach that integrates various competencies from subjects into various themes and assessment process. The assessment process in the 2013 curriculum is not only to assess the final outcome of learning but the assessment process is also conducted in the learning implementation, assessment is conducted on aspects of knowledge, attitudes, and skills (Mamat Ruhimat, 2018). Therefore, the 2013 curriculum strongly recommends that teachers conduct authentic research. However, the teachers did not research because they still did not understand the procedure and instruments were not detailed. The assessment system used by teachers was also generally paper and pencil test because they assess quite practicel in terms of energy, cost, and time (Yuni Pantiwati, 2013). Based on the results of observations in the second grade of SD Negeri (public elementary school) Pandeanlamper 01 Semarang, it showed that authentic assessment had been applied by the teacher in the learning process. The teachers had also conducted authentic assessments that included the assessment of attitudes, knowledge, and skills. However, the teachers still faced difficulty in implementing authentic assessment during learning process. Then, the teachers decided to use simple assessment instruments. When these problems can not be handled well, the teacher will not use the assessment optimally and the problem will continue with a subjective attitude assessment that is based on its function.

An authentic assessment is a real assessment and proven by the performance and or results that have been made by studentsn(Mustikarani \& Ruhimat, 2018: 149 (Mamat Ruhimat, 2018)). (Sani, 2014)) Authentic assessment is a type of assessment that directs students to demonstrate the needed skills and competencies to overcome problems and situations found in the real world. The authentic assessment is the activity of evaluating students that emphasize the process and results from a variety of assessment instruments that are adjusted to the competency demands existing in the competency standards or core competencies and basic competencies (E. Nurhayati \& Ahmad, 2018). On the other hand, Kunandar 2013 (Ari Astriyandi, Umi Chotimah, 2016) states that authentic assessment is an assessment that pays attention to aspects of attitude, knowledge, and skills competencies. ((Curriculum Center, 2009 (Umami, 2018) states that authentic assessment is a process of gathering, reporting, and using information about student learning outcomes by applying the principles of assessment, ongoing implementation, authentic, accurate, and consistent evidence as public accountability. The existence of authentic assessment makes students more motivated in learning because what they do is assessed and will affect their learning outcomes. Johnson (2002:165) in (Basit \& Wardana, 2016) explains that authentic assessment provides broad opportunities for students to show what they have learned during learning. The authentic assessment makes students aware of the importance of learning process. Whereas (Ari Astriyandi, Umi Chotimah, 2016) states that authentic assessment requires students to demonstrate their knowledge, skills, and students must be able to produce answers or products from theoretical knowledge. Thus, students will feel the learning process more meaningful. To fulfill the assessment process, there are many types of assessments that exist in learning implementation. (Wahyuni, 2012:68 (Basit \& Wardana, 2016) states that authentic assessment has 6 forms, namely: (1) performance assessment, (2) portfolio assessment, (3) project assessment, (4) peer assessment, (5) self assessment, and (6) attitude assessment Techniques used by educators for the attitude assessment are observation, self-assessment, peer assessment by students and journals. Knowledge competence assessment are done through written tests, oral tests, and assignments 259 competence assessment are done through performance assessment that requires students to demonstrate a certain competency using practice tests, projects, and portfolio assessments.

A similar study about this topic had been conducted by other researchers, a study conducted by (Mamat Ruhimat, 2018) states that a test is used dominant than non-test forms, as well as on Daily Tests, Midterm Test (UTS), and Final Test (UAS) ). In addition, only a few of teacher respondents made questions by referring to the grid, and there were even teachers who did not make the grid. The measuring instruments were not made through the stage of validity and reliability test. Teacher respondents had not shown improvement in development quality of student learning outcomes measurement tools. The researchers recommended all parties to 
improve, accustom, and supervise teachers to make learning outcomes measurement tools, especially for social science teachers. (E. Nurhayati \& Ahmad, 2018) state that history teachers have a good understanding of assessment authentic in the 2013 curriculum. The history teacher has conducted the knowledge assessment and skills assessment well whereas in terms of the analysis and report of authentic assessment results, the teachers use online value processing software; the obstacles experienced by history teachers are the diversity of students with different backgrounds and characters, while the quality of students, the availability of facilities and learning resources, and the existence of value processing software support the teacher to implement authentic assessment. (Ari Astriyandi, Umi Chotimah, 2016) state that the ability of teachers to implement authentic assessment in learning PPKn (Civics) in Indralaya 1 High School is in the poor category. It is proven from the percentage of authentic assessment implementation around $46.8 \%$, the incompatibility of questions with the material being taught and there is no assessment rubric on the attitude and skills assessment instruments.

Based on the explanation, it can be said that authentic assessment is one of the assessment instrument that is done to measure student learning outcomes. Many problems are still faced by teachers relating to authentic assessment, therefore it is designed a study that aims at analyzing teacher pedagogical competence of authentic assessment implementation in the thematic learning of the second grade SD Negeri (public elementary school) Pandeanlamper 01 Semarang. It is expected that a solution for the problem faced by teacher can be found and used by the teacher in order to develop and use authentic assessment.

\section{Method}

The research approach used in this study was a qualitative. Moleong (2014: 6) states that qualitative research emphasized on the obtained data in the form of sentences rather than numbers using statistical procedures. In qualitative research, data are obtained from various sources, data collection techniques (triangulation) and the study is conducted continuously until the data saturated. Sugiyono (2017: 333). In this study, research instruments were researcher (human instruments), observation, interviews, and documentation. Data collection procedures included observation, interviews, and documentation. In this study, data analysis methods applied model of Miles and Huberman (in Sugiyono, 2017: 337-345), namely data reduction, data display, and conclusion drawing/verification.

\section{Result and Discussion}

In this study, the implementation of authentic assessment in thematic learning was discussed futrher which included teacher understanding of authentic assessment implementation, the implementation of attitude competency assessment, the implementation of knowledge competency, and implementation of skill competency in learning thematic of the second grade in SD Negeri (public elementary school) Pandeanlamper 01 Semarang.

\section{Teacher Knowledge about the Implementation of Authentic Assessment in Thematic Learning}

Based on the results of the study, it can be said that Mrs. Wuri Indayani used authentic assessment as a thematic learning assessment in the 2013 curriculum. The result is inline with the Attachment Copy of The Minister of Education and Culture of Republic of Indnnecia (Permendikbud) Number 104 of 2014 concerning Learning Outcomes Evaluation by Educ 260 Primary and Secondary Education which states that the 2013 curriculum requires the use of authentic assessment.

Based on the results of the study, it was found that the definition of authentic assessment based on Mrs. Wuri Indayani opinion is a comprehensive assessment both of attitude aspect consisting of social and religious attitudes, knowledge aspect, and skills aspect that are done continuously. The authentic assessment is a real assessment and it is proven by the performance and or results that have been made by students (Mustikarani \& Ruhimat, 2018: 149 (Mamat Ruhimat, 2018)). Sani, (2014) states that authentic assessment is a type of assessment that directs students to demonstrate the needed skills and competencies to overcome problems and situations encountered in the real world. The authentic assessment is the activity of student evaluation that emphasize the process and results with a variety of assessment instruments. It is adjusted to the competency demands that exist in competency standards or core competency and basic 
competency (E. Nurhayati \& Ahmad, 2018). Meanwhile, Kunandar 2013 (Ari Astriyandi, Umi Chotimah, 2016) states that authentic assessment is an assessment that pays attention to competency aspects of attitude, knowledge, and skills. ((Curriculum Center, 2009 (Umami, 2018) states that authentic assessment is a process of gathering, reporting, and using information about student learning outcomes by applying the principles of assessment, ongoing implementation, authentic, accurate, and consistent evidence as the public accountability.

Based on the study, it can be seen that the problems faced by schools in implementing authentic assessments are that teachers IT mastery and teacher age (approaching retirement). It is based on Mrs. Miryarti opinion. To overcome these problems, the old teachers are assisted by young teachers. And for the supporting and inhibiting factors, namely the availability of computer/laptop facilities, and age affect the willingness to learn.

\section{Implementation of Attitude Competency Assessment in Thematic Learning}

Based on the results of the study, it can be seen that the observed aspects in attitude competency consist of social and religious attitudes. The following assessment techniques were used by Mrs. Wuri Indayani in assessing the competency of attitudes using journal assessment Based on research, it is known that during observation was done by researcher, and Mrs. Wuri Indayani used a journal assessment to assess the competency of religious and social attitudes. Journal assessments were conducted by Mrs. Wuri Indayani during learning or outside learning, but only on certain event both positive and negative events. Journal assessment is one of the methods used by teachers to take notes and document what students do. Umi Salamah (2018) states that journal is an assessment instrument that is used to collect teacher notes inside and outside the classroom including the observation information about student attitudes and behavior. In addition, Imron (2011) states that learning journals are collections of notes, observations, thoughts, and relevant materials that are arranged in a certain period, usually made in a certain learning period. The existence of teacher's journal is used to record all student matters and it can be used as a reference in making decisions relating to students' attitude during the learning process. Imron (2011) adds that learning journals can be used as follows: 1) Giving a real description of material mastery or someone's experience. 2) Showing the development of someone's learning. 3) Maintaining a recording of someone's thoughts and ideas through learning experiences. 4) Assisting to identify strengths, weaknesses, and choices in someone's learning.

Based on the results of the study, journal assessments are inseparable from the obstacles, it is known that the obstacle in conducting journal assessments is the student attitudes can be observed directly by the teacher, especially on learning outside process.

\section{The Implementation of Knowledge Competency Assessment in Thematic Learning}

Based on the results of the study, it can be seen that the implementation of authentic assessment in thematic learning based on the assessment of knowledge competencies was conducted with a variety of techniques, namely: written tests, oral tests, and assignments. Alimuddin (2014) states that the assessment of knowledge can be interpreted as an assessment of intellectual potential including factual, conceptual, procedural, and metacognitive knowledge. However, only a few techniques were used by Mrs. Wuri Indayani, as follows:

\section{Written test}

Based on the results of the study, it can be seen that the teacher applied written tests to assess students' knowledge competence. Written tests were used by Mrs. Wuri Indayani in Daily Test (UH) and Examination (U) in each lesson. In this written technique, Mrs. Wuri Indayani gave some questions in written form, both question sheets or it was written on the board. In addition, the answers of question were written on the assignment book. Written test is a test in which questions and answers are written in the form of multiple choice, filling, true or false, matching, and essay (S. Nurhayati, 2019). In addition, Sani (2016) states that the written test is a test of questions given to students in written form, and students answer in written form.

Based on the results of the study, it was found that the question used by teacher was in the form of essay. Written test in form of essay is a set of questions in the form of assignments, questions that require students to organize and express their answers in their own wrnrdc (Muttaqin \& Kusaeri, 2017). Asmawi Zaenul and Noehi Nasution (Muttaqin \& Kusaeri, 2012261 that written tests in the form of an essay are items consisting questions whose answers are done by expressing the thought of participants.

Based on the results of the study, it was also known that Ms. Wuri Indayani prepared the questions before conducting the assessment. The implementation of exam assessment was done in 
each lesson to check the completeness of the learning, and the daily test was done at the $6^{\text {th }}$ learning meeting or the end of the sub themes. The assessment was done and distributed directly to each student. The implementation of competency assessment of student knowledge through written test techniques was inseparable from obstacles. Based on the results of the study, it is known that the obstacles in assessing student knowledge through written test techniques, is the large budget for multiplying the questions. Thus, teachers need a great fund.

\section{Assignment}

Based on the results of the study, it was known that the teachers applied the assignment technique to assess students' knowledge competency. Homework was given by the teacher as the assignment instrument. The results of the study are in line with Sani (2016: 89) that states the assignment instrument in form of homework and or projects are done individually or in groups.

Based on the results of the study, it was also known that before conducting the assignment, Mrs. Wuri Indayani prepared firstly the questions. The assignment was not conducted by Mrs. Wuri Indayani every day and then all the collected task were assessed. The assessment implementation of students' knowledge competency through the assignment technique was inseparable from the obstacles. Based on the results of the study, the obstacle is on students side who do not submit assignments on time.

\section{The Implementation of Skills Competency Assessment in Thematic Learning}

Based on the result of the study, it was known that the implementation of authentic assessment in thematic learning based on teacher skills competency assessment only applied the following assessment techniques:

Product

Based on the study, it was known that Mrs. Wuri Indayani applied product assessment to assess students' skills competency. Before conducting the assessment, Mrs. Wuri Indayani made preparations such as giving directions to students about what needs to be prepared and brought. The product assessment was conducted directly by Mrs. Wuri Indayani. And the results of the product assessment were not delivered directly by Mrs. Wuri Indayani. Taufina, 2009 (Fitria Wahyu Pinilih, Rini Budiharti, 2013) states that the product assessment is an assessment of students' skills in applying the knowledge that they have in the form of a product, and the assessment of the product quality. However, the assessment can not be separated from the obstacles, some students sometimes forget to bring tools and materials that will be used to make a product so the teacher prepares extra material as a reserve for students who do not bring materials.

The present study is in line with some previous study, namely Mamat Ruhimat (2018) states that the measurement of the test is more dominant than the non-test, both on the Daily Tests, Midterm Test (UTS), and Final Test (UAS). In addition, only a small proportion of teacher respondents made questions by referring to the grid, and there were even teachers who did not make the grid. The measuring instrument did not meet the validity and reliability test stages. Teacher respondents had not shown improvement in development quality of measurement instrument on student learning outcomes. The researcher recommended all parties to improve, accustom, and supervise teachers to make assessment instrument on student learning outcomes, especially for social science teachers. E. Nurhayati \& Ahmad (2018) states that history teachers have a good understanding of authentic assessment in the 2013 curriculum. The history teachers have conducted the knowledge assessment and skills assessment well while in terms of the analysis and report of the authentic assessment results, the teachers use online value processing software; the obstacles experienced by history teachers are students diversity with different backgrounds and characters, while the supporting factors in implementing authentic assessment are the students quality, the availability of facilities and learning resources, and the existence of value processing software. Ari Astriyandi, Umi Chotimah (2016) state that the ability of teachers to implement authentic assessment in learning Civics in Indralaya 1 High School is in the poor category. It is proven from the percentage of the authentic assessment implementation around $46.8 \%$, the incompatibility of essay test with the material being taught and the absenc 262 assessment rubric on the attitude and skills assessment instruments

\section{Conclusion}


Based on the results and discussion of the study, it can be concluded that the teacher has conducted several types of authentic assessments such as Journal Techniques to assess attitudes, essay tests, and assignments for knowledge abilities and for teacher skills in using product research. However, there are still some obstacles experienced by teachers in using authentic assessment, namely the difficulty of observing students' attitudes in the learning process, the limited costs for making questions, and students who are not disciplined in preparing products and others. Therefore, the teacher should not delay researching students' performance.

\section{References}

Alimuddin. (2014). Penilaian Dalam Kurikulum 2013. Seminar Nasional Pendidikan Karakter, 01(1), 23-33.

Ari Astriyandi, Umi Chotimah, E. E. F. (2016). Kemampuan Guru Menerapkan Penilaian Autentik Dalam Pembelajaran Ppkn. Jurnal Bhinneka Tunggal Ika, 3(4), 187-198.

Basit, A., \& Wardana, L. A. (2016). Pengembangan Perangkat Asesmen Autentik Dalam Pembelajaran Pendidikan Kewarganegaraan. Jurnal Ilmiah Pendidikan Pancasila Dan Kewarganegaraan, 1(2), 73-78. Https://Doi.Org/10.17977/Um019v1i22016p073

Fitria Wahyu Pinilih, Rini Budiharti, E. Y. E. (2013). Pengembangan Instrumen Penilaian Produk Pada Pembelajaran Ipa Untuk Siswa Smp. Jurnal Pendidikan Fisika, 1(2), 23-27.

Imron, K. \& A. (2011). Penerapan Teknik Penilaian Learning Journal Pada Model Pembelajaran Berbasis Masalah Untuk Meningkatkan Hasil Belajar Siswa Materi Pokok Segiempat. Kreano: Jurnal Matematika Kreatif-Inovatif, 2(1), 57-71. Https://Doi.Org/10.15294/Kreano.V2i1.1246

Kunandar. (2014). Penilaian Autentik (Penilaian Hasil Belajar Peserta Didik Berdasarkan Kurikulum 2013). Rajawali Pers.

Mamat Ruhimat. (2018). Kompetensi Pembuatan Instrumen Pengukuran Hasil Belajar Oleh Guru Ips Smp Di Kota Bandung. LENTERA PENDIDIKAN, 21(2), 176-187.

Muttaqin, M. Z., \& Kusaeri, K. (2017). Pengembangan Instrumen Penilaian Tes Tertulis Bentuk Uraian Untuk Pembelajaran Pai Berbasis Masalah Materi Fiqh. Jurnal Tatsqif, 15(1), 1-23. Https://Doi.Org/10.20414/J-Tatsqif.V15i1.1154

Novauli. M, F. (2015). Kompetensi Guru Dalam Peningkatan Prestasi Belajar Pada Smp Negeri Dalam Kota Banda Aceh. Jurnal Administrasi Pendidikan : Program Pascasarjana Unsyiah, 3(1), 45-67.

Nurhayati, E., \& Ahmad, T. A. (2018). Implementasi Penilaian Autentik Dalam Pembelajaran Sejarah Di SMA Negeri 1 Semarang. Indonesian Journal Of History Education, 6(1), 21-30.

Nurhayati, S. (2019). Pengelolaan Penilaian Hasil Belajar Mata Pelajaran. Jurnal Balai Diklat Keagamaan Bandung, XIII, 154-161.

Sani, R. A. (2014). Pembelajaran Saintifik Untuk Implementasi Kurikulum. Bumi Aksara.

Sani, R. A. (2016). Penilaian Autentik. Bumi Aksara.

Shabir, M. (2015). Kedudukan Guru Sebagai Pendidik: (Tugas Dan Tanggung Jawab, Hak Dan Kewajiban, Dan Kompetensi Guru). Jurnal AULADUNA, 2(2).

Umami, M. (2018). Penilaian Autentik Pembelajaran Pendidikan Agama Islam Dan Budi Pekerti Dalam Kurikulum 2013. Jurnal Kependidikan, 6(2), 222-232. Https://Doi.Org/ 10.24090/Jk.V6i2.2259

Umi Salamah. (2018). Penjaminan Mutu, Penilaian Pendidikan. Evaluasi, 2(1), 274-293.

Yovi Anggi Lestari Dan Margaretha Purwanti. (2018). Hubungan Kompetensi Pedagogik, Profesional, Sosial, Dan Kepribadian Pada Guru Sekolah Nonformal X. Jurnal KEPENDIDIKAN, 2(1), 197-208.

Yuni Pantiwati. (2013). Hakekat Asesmen Autentik Dan Penerapannya Dalam Pembelajaran Biologi. Jurnal Edukasi Matematika Dan Sains, 1(1). 